Revista do SELL

v. 6 , no. 2

ISSN: $1983-3873$

\title{
A TRANSCENDÊNCIA DESVIADA ENQUANTO CRÍTICA RELIGIOSA DE DOSTOIÉVSKI NO ROMANCE "O IDIOTA"
}

\author{
THE INVERTED TRANSCENDENCE AS DOSTOEVSKY'S CRITICISM OF RELIGION IN \\ THE NOVEL THE IDIOT
}

Renê Wellington Pereira Fernandes

Universidade Estadual de Campinas

\begin{abstract}
RESUMO: A questão religiosa apresentada no romance O ldiota (pelo qual Dosteiévski deu mostra clara de predileção) será aqui abordada em uma perspectiva dialógica, na qual o conceito de transcendência desviada, de René Girard, e a ideia de crítica religiosa de Dostoiévski, de Luiz Felipe Pondé, servirão de proposta de leitura. Não obstante, salientar-se-á que ambas as teorias elencadas são tanto continentes quanto contingentes de outras não menos importantes; a saber, respectivamente: o desejo triangular (também chamado de "mimético" ou "metafísico", que funda, para Girard, o estatuto de unicidade romanesca), e a "filosofia da desgraça", que, para Pondé, configura-se na crítica denunciadora da "liberdade incriada do Homem" e de sua "sobrenaturalidade esquecida". Diante disso, o objetivo principal será o de demonstrar como a crítica religiosa de Dostoiévski, contida em seu décimo primeiro livro, consiste num insight ainda mais desconcertante: ela emana de um movimento dialético, o qual ao mesmo tempo em que promove um "Esforço supremo em criar uma perfeição puramente humana e individualista" demonstra que "o romance volta-se, em suma, contra sua própria 'ideia"' (GIRARD, 2011, p. 75). $\mathrm{Na}$ verdade, o que o autor russo faz é submeter à sua crítica religiosa o "projeto moderno o qual chama de 'virtude sem o Cristo' ou 'a salvação sem Deus', um projeto de aposta na natureza." (PONDÉ, 2003, p. 258).
\end{abstract}

PALAVRAS-CHAVE: transcendência desviada; crítica religiosa de Dostoiévsky; ironia dosteivskiana.

ABSTRACT: The religious question presented in the novel The Idiot (for which Dostevsky gave a clear display of predilection) will be dealt here in a dialogical perspective, in which the concept of inverted transcendence by René Girard and the idea of Dostoevsky's criticism of religion by Luiz Felipe. However, it will be pointed out that both theories listed are both continents and contingents of others no less important; namely, triangle of the desire (also called "mimetic" or "metaphysical", which, for Girard, founds the status of Romance unity), and the "philosophy of doom", which, for Pondé, criticism denouncing the "uncreated freedom of man" and his "forgotten supernaturality." The main purpose of this is to demonstrate how Dostoevsky's religious critique, contained in his eleventh book, is an even more disconcerting insight: it emanates of a dialectical movement which, while promoting a "supreme effort to create a purely human and individualistic perfection", demonstrates that "the romance turns, in short, against its own" idea "(GIRARD, 2011, 75). In fact, what the Russian author does is to submit to his religious criticism the "modern project which he calls 'virtue without the Christ' or 'salvation without God', a project of betting on nature." (PONDÉ, 2003, 258)

KEYWORDS: inverted transcendence, Dostoevsky's criticism of religion, Dosteivskian irony. 


\title{
Revista do SELL
}

v. 6 , no. 2

ISSN: $1983-3873$

\begin{abstract}
Eu amo sempre os desprezados e os esquecidos, como a abelha prefere a flor desconhecida da colmeia; é mais puro e abundante o mel das flores ignoradas, e mais suave a bondade das pessoas que ninguém lembra... Eu amo os que têm fome, porque aos dar-lhes do meu pão, o gesto com que recebem abençoa o pão das minhas searas. Eu amo todos os que sofrem, porque a sua virtude é como a das plantas cheirosas, que, quanto mais se torturam e pisam, mais alto elevam o perfume... (Nuno de Montemor)
\end{abstract}

O aspecto inerente ao cenoticismo cristão, que perpassa a produção literária de Dostoiévski, foi denominado pelo niilismo racional de hiper-religiosidade. Obviamente, este último termo traz consigo as implicações patológicas da epilepsia e acaba por instaurar, como pedra de toque para as questões que envolvam a técnica literária desse autor russo, o aspecto autoral calcado na revelação-inspiração extática; homologada, por um lado - não assumido explicitamente -, pela mistificação da doença e, por outro, pelo respaldo médico-científico de cunho psicanalítico.

Ora, o primeiro conceito foi recuperado em meio à análise crítico-biográfica do escritor norte-americano Joseph Frank (2003), já o segundo pertence às considerações filosóficas que tece Luiz Felipe Pondé (2003), ao passo que o terceiro à hermenêutica do também filósofo Flávio Rocha Lima Paranhos (2012). Há de se convir, assim sendo, que a religiosidade, e neste caso mais especificamente a religiosidade de cunho cristão, é um elemento recorrente e irrefutável em grande parte dos trabalhos do autor de O Idiota.

Sendo assim, em uma nota de rodapé, Frank recupera a acepção do termo cenoticismo de acordo com a ortodoxia russa, sendo que:

Um dos aspectos distintivos da tradição religiosa russa, na definição de seu maior historiador moderno, G.P.Fedótov, é a enfatização desse aspecto da fé cristã. Segundo a tese de Fedótov, aceita de modo geral, no cerne da espiritualidade russa encontra-se o Cristo sofredor e humilhado. (FRANK, 2003, p.423).

Essa distinção para Frank é necessária, visto que o cenoticismo ocupa uma das berlindas do debate entre católicos e protestantes. De modo que, para o credo católicoromano, a ideia de que quando se fez carne Jesus tenha abdicado ou simplesmente anulado alguns aspectos de sua divindade - sobretudo aqueles que the tornam homólogo a Deus, como a onisciência, a onipotência e a onipresença - constitui uma heresia.

Assim, o "esvaziamento" (do grego kenosis) de atributos inerentes à natureza divina, aceito e pregado pelos protestantes (ou pela maioria deles), implica uma relação 


\section{Revista do SELL}

v. 6 , no. 2

ISSN: $1983-3873$

de exclusão: para que Jesus pudesse padecer os males que lhe foram impostos na Terra, seria necessário assumir a dimensão humana e ao fazê-lo, consequentemente, deveria privar-se da esfera divina.

Por outro lado, o contra-argumento dos teóricos católicos fundamenta-se na hipótese de que o cenoticismo tenha-se originado de uma interpretação equivocada do segundo capítulo da carta que Paulo escreveu, como forma de exortação, aos filipenses; mais especificamente dos versículos 5 a 8 , em cujas linhas, Paulo trata diretamente do exemplo de humilhação de Cristo que "a si mesmo se esvaziou, assumindo a forma de servo, tornando-se em semelhança de homens"1.

É evidente que, sendo "o príncipe Mychkin², o produto das ruminações teológicas de Dostoiévski" 3, poderíamos cogitar com base em um exercício de raciocínio abdutivo que, em relação ao que foi referido nos dois parágrafos precedentes, a caracterização (cenótica) da personagem do príncipe seria uma transubstanciação literária de um dos motivos mais fortes da narrativa: o quadro Cristo Morto, de Hans Holbein. Tamanha é sua importância, que Barbara Fister, em um artigo cujo título inicia-se pertinentemente pela palavra Threshold (limiar), declara ser o quadro uma afronta à tradição ortodoxa da igreja russa, uma vez que problematiza uma concepção de ascese distinta daquela aceita e referida pela igreja ortodoxa:

O Cristo morto de Holbein captura o olhar fascinado dos personagens $\mathrm{n}$ ' $\mathrm{O}$ idiota, porque representa o que está quase além da representação. A imagem não mediada de um ser humano morto e brutalmente torturado é bastante contraditória em relação às imagens mais populares de um Cristo belo (que Ipolit considera a norma) e à iconografia da imagem russa. Ver imagens sagradas, na fé ortodoxa russa, é uma forma de adoração que enfatiza o esforço do homem em direção à piedade, uma forma de transformação por meio do encontro com o divino: o ícone formando uma janela através da qual o divino pode ser vislumbrado. Assim, a humanidade de Cristo não é um assunto próprio para representação à custa de sua divindade. De acordo com Leonid Ouspensky, "o ícone é uma semelhança, não de um protótipo animado, mas deificado, isto é, é uma imagem (convencional, é claro) não de carne corruptível, mas de carne transfigurada, radiante de luz divina... consequentemente, tudo o que

\footnotetext{
${ }^{1}$ Bíblia Sagrada, 1993, p. 233 do NT.

${ }^{2}$ A onomástica das personagens é usada aqui conforme consta na tradução de $O$ idiota, feita por Paulo Bezerra e publicada pela Editora 34, assim como encontrada, também, no livro Dostoiévski: Os anos Milagrosos, de Joseph Frank, traduzido por Geraldo Gerson de Souza e publicado pela Edusp.
}

${ }^{3}$ Frank, 2003, p.420 


\section{Revista do SELL}

v. 6 , no. 2

ISSN: $1983-3873$

lembra a carne humana corruptível é contrário à própria natureza do ícone" (35-36). Todos os aspectos do Cristo de Holbein vão contra a tradição ortodoxa. No Ocidente, desde o Renascimento, a natureza humana de Cristo foi celebrada na arte, mas na igreja oriental, é a sua divindade que é a sua característica preeminente. Um ponto central na teologia ocidental é que o homem é pecaminoso e deve ser redimido através de Deus tomando forma humana. A igreja ortodoxa se concentra menos no estado caído do homem do que em seu potencial para imitar Deus, para redimir-se mediante a contemplação da imagem de Deus. Por isso, o Cristo de Holbein viola as convenções iconográficas ortodoxas, retratando, em um sentido extremo, sua humanidade, excisando o seu divino natureza. (FISTER, 1996, on-line) ${ }^{4}$

Portanto, há, aqui, uma religiosidade que, além de apresentar um cristianismo de matiz não ocidental, fique aqui ressaltado, também não poderia ser denominada propriamente de oriental ou ortodoxa. De qualquer forma, novamente, a religião é o fulcro de mais uma obra narrativa de Dostoiévski. Tanto é assim que Pondé vê em Dostoiévski "um pensador religioso" 5. De acordo com ele, Dostoiévski foi grandemente influenciado pela mística ortodoxa, e, portanto:

O páthos divino é uma intuição importante, porque os personagens de Dostoiévski, que são figuras "divinizadas", cujos dois grandes exemplos são Míchkin (O idiota) e Aliócha, - o Alieksiéi, de Os irmãos Karamázov -, são claramente figuras que sofrem desse páthos divino, o que, na obra do escritor russo, de forma nenhuma implica em qualquer tipo de sucesso no mundo. Estarmos em comunicação com Deus ou invadidos pela Transcendência não significa necessariamente que possamos fazer sucesso, que possamos nos dar bem na vida. (PONDÉ, 2003, p.58).

\footnotetext{
4 "Holbein's dead Christ captures the fascinated gaze of the characters in The Idiot because it represents that which is nearly beyond representation. The unmediated image of a dead and brutally tortured human being is one which is quite inconsistent with the more popular images of a beautiful Christ (which Ippolit considers the norm) and with the iconography of the Russian icon. Viewing holy images, in the Russian Orthodox faith, is a form of worship which emphasizes man's striving toward godliness, a form of transformation through encounter with the divine, the icon forming a window through which the divine can be glimpsed. Thus, Christ's humanity is not a proper subject for representation at the expense of his deity. According to Leonid Ouspensky, "the icon is a likeness not of an animate but deified prototype, that is, is an image (conventional, of course) not of corruptible flesh, but of flesh transfigured, radiant with divine light . . . consequently, everything which reminds of the corruptible human flesh is contrary to the very nature of the icon"(35-36). Every aspect of the Holbein Christ flies against Orthodox tradition. In the West since the Renaissance, the human nature of Christ has been celebrated in art, but in the Eastern church it is his deity that is his preeminent characteristic. A central point in Western theology is that man is sinful and must be redeemed through God taking human form. The Orthodox church focuses less on the fallen state of man than on his potential to emulate God, to redeem himself through contemplation of the image of God. Hence, the Holbein Christ violates Orthodox iconographic conventions by portraying, in an extreme sense, his humanity, excising his divine nature." (FISTER,1996, on-line)
}

${ }^{5}$ Pondé, 2003. 


\section{Revista do SELL}

v. 6 , no. 2

ISSN: $1983-3873$

E, já que a epilepsia do príncipe Mychkin, na visão de alguns críticos, consistiria na manifestação do affectus ${ }^{\beta}$, o que significaria, em se tratando de uma hipótese de leitura suscitada, pensarmos que:

"[...] não seria interessantíssima uma discussão acerca da influência de doenças em obra de arte? A hiper-religiosidade de Dostoíévski e a demência neurossifilítica de Nietzsche (e a loucura de Artaud e depressão de Van Gogh, etc.) são os verdadeiros autores de suas obras? E se fossem, faz diferença?" (PARANHOS, 2012, p.29).

A essa problematização, encetada em um artigo da Revista Filosofia, Paranhos responde por meio de um hiato, que comporta em si a promessa de considerações futuras a respeito. Note-se, entrementes, que tal abordagem confere ao tema um caráter positivo, posto que a epilepsia "foi por muito tempo tido como doença sagrada, cercada de superstição e misticismo" ·.

Mas enquanto essa análise mais acurada de Paranhos a respeito do (sugerido) caráter hiper-religioso da obra de Dostoíévski não toma corpo, opta-se, neste trabalho, em abordar a questão religiosa apresentada no romance $O$ ldiota (pelo qual Dosteiévski deu mostra clara de predileção) em uma perspectiva dialógica, na qual o conceito de transcendência desviada, de René Girard, e a ideia de crítica religiosa de Dostoiévski, de Luiz Felipe Pondé - guardadas suas devidas medidas e proporções de especificidade -, tangem um mesmo ponto e, assim, servem como proposta de leitura.

Não obstante, é importante salientar que ambas as teorias elencadas são tanto continentes quanto contingentes de outras não menos importantes; a saber, respectivamente: o desejo triangular (também chamado de "mimético" ou "metafísico", que funda, para Girard, o estatuto de unicidade romanesca), e a "filosofia da desgraça", que, para Pondé, configura-se na crítica denunciadora da "liberdade incriada do Homem" e de sua "sobrenaturalidade esquecida".

\footnotetext{
${ }^{6}$ Trilhando a senda da "fenomenologia da religião", feita por Abraham Joshua Heschel, Pondé aponta para a sutil nuance etimológica entre intelellectus e affectus, relatando que: "Recentemente, um doutorando em ciências da religião na Alemanha dizia-me que a grande tragédia do estudo da religião no Ocidente está no fato de a teologia, em geral, haver-se concentrado na dinâmica do intellectus e não do affectus. Entretanto, como já vimos, a mística ortodoxa é uma grande exceção a essa tendência, uma vez que se concentra no affectus. Da mesma forma, Heschel, na sua condição de pesquisador da religião judaica, elege como foco da sua atenção o affectus, o páthos. Ao passarmos do páthos ao affectus, do grego para o latim, estaremos no mesmo sentido, isto é, a (quase) 'afecção' que Deus causa na pessoa mística, como se fosse uma invasão ou uma 'visita', como nos fala a mística ortodoxa. É nesse sentido que o místico profeta é um animal visitado (por Deus)”. PONDÉ, 2003, pp. 57-8.
} 


\section{Revista do SELL}

v. 6 , no. 2

ISSN: $1983-3873$

Portanto, far-se-á necessário, para discorrer a respeito da "transcendência desviada" e da "crítica religiosa de Dostoiévski", evocar, ainda que por vezes muito brevemente, alguns desses conceitos imanentes.

Dessa forma, o primeiro a ser posto em pauta, dado seu caráter incontrastável, é o conceito de "desejo mimético" desenvolvido por Girard, em cuja funcionalidade poder-seia observar uma antropologia negativa; uma vez que põe à mostra a falta de espontaneidade concernente ao ato de desejar realizado pelo (e no) ser humano.

O que tal teoria evidencia, portanto, é a presença de um mediador entre o sujeito e o objeto, sendo que, uma vez apreendida essa mediação por alguns escritores, passam suas obras a desvelar o automatismo das relações humanas em graus variados da representação ficcional. Ao resultado estético e, ao mesmo tempo, filosófico, dessa representação, Girard chamou "verdade romanesca".

Por outro lado, em termos dialéticos, a simples existência dessa premissa - a da "verdade romanesca" - implica sua outra "face", ou seja, a da mentira, que para Girard é romântica (porquanto idealizada) e, portanto, constitui-se em "mentira romântica". Proclamam-na ou a ela não atentam, observa Girard, todos aqueles autores que escrevem obras em cujas tramas "Não há mediador, há apenas o sujeito e o objeto" 7 , todos aqueles autores que, a respeito do desejo, pensam que "Sempre se pode representá-lo por uma simples linha reta ligando o sujeito e o objeto" 8 . Por isso, a tais autores o filósofo francês não dispensa sequer uma linha em seu "Mensonge romantique et Vérité romanesque".

Partindo desse preâmbulo, encontra-se em O Idiota, "sentimentos e desejos que as personagens não experimentariam espontaneamente" 9. Gánia Ívolguin, por exemplo, deseja ainda com maior intensidade fazer-se agradável e natural ao círculo matriarcal das lepántchinas, sobretudo à Aglaia, à medida que o príncipe Mychkin triunfa despreocupadamente. Tal propósito é explicitado no inquérito ao qual o jovem contabilista submete o forasteiro, assim que deixam a casa de Lisavieta Prokófievna:

Sim, mas, por quê, diabos que o carreguem! O que é que o senhor fez lá de tão especial? Por que caiu no agrado delas? Escute - estava agitado a

\footnotetext{
${ }^{7}$ GIRARD, 2009, p.26.

${ }^{8}$ Loc. cit.

${ }^{9}$ GIRARD, 2009
} 


\section{Revista do SELL}

v. 6 , no. 2

ISSN: $1983-3873$

não poder mais (nesse instante tudo dentro dele estava de certo modo desconexo e fervia em desordem, de tal forma que não conseguia juntar as idéias) - escute, porventura o senhor não pode ao menos dar um jeito de se lembrar e atinar em ordem o que precisamente disse lá, todas as apalavras, desde o início? Não notou alguma coisa? (DOSTOIÉVSKI, 2002, p. 113).

Perceba-se que, nesse ponto, Gánia reconhece que aquilo que tentou, por anos enfiado na intimidade da família do general Ivan Fiodorovitch lepántchin, o príncipe conseguiu "duas horas depois do primeiro encontro" ${ }^{10}$. Esse mesmo efeito causador da inveja, do ciúme e, por conseguinte, do "ódio impotente" ${ }^{11}$, Mychkin provoca em outras personagens, quando com ele estas se deparam irremediavelmente.

Desse modo, o príncipe Mychkin, embora desde o primeiro momento em que entra em cena pareça “... sofrer de uma absoluta falta de autoconsciência”, configurada em sua total falta de preocupação com “... algo que consideramos, hoje, fundamental - a autoestima" 12 - faz com que as demais personagens do romance o encarem "como o modelo da própria consciência" ${ }^{13}$. Talvez seja por isso que, como observou Frank, "O próprio Gánia chega mais tarde a pedir desculpas ao Príncipe e confessa que, embora planeje prosseguir com o casamento vergonhoso, ele (o príncipe) o faz sentir-se um patife" 14 .

Provavelmente, para Gánia, esse seja o motivo de vivenciar uma experiência ambígua - em relação ao modelo que, para ele, vai se constituindo o príncipe -, na qual "o sujeito experimenta por esse modelo um sentimento dilacerante formado pela união destes dois contrários que são a mais submissa veneração e o mais intenso rancor" ${ }^{15}$. Fica claro, desse modo, que o anseio de Gánia por ter-se em conta de estimado, apreciado e bem-quisto em meio às iepántchinas, por ele é nutrido veementemente sem que, contudo, nele tenha-se originado espontaneamente.

Nesses termos, encarnar no príncipe todas as suas frustrações torna-se um procedimento que, ao mesmo tempo em que faz Gánia capitular diante da consciência de

\footnotetext{
${ }^{10}$ Loc. cit.

${ }^{11}$ GIRARD, 2009.

${ }^{12}$ PONDÉ, 2003, p.252

${ }^{13}$ FRANK, 2003, p.439.

${ }^{14}$ Op. cit., p.429.

${ }^{15}$ GIRARD, 2009, p. 34
} 


\section{Revista do SELL}

v. 6 , no. 2

ISSN: $1983-3873$

si mesmo (personificada em Mychkin), também coloca em funcionamento, ainda que inconscientemente, o mecanismo do "bode expiatório"; cuja denominação e conotação Girard empresta do campo teológico.

No que concerne a essa circunstância, um quadro ilustrativo é a situação desencadeada pela descoberta de um retrato de Nastácia Filíppovna; descoberta essa que, feita por Varvara Ardaliónovna, reinstala a tensão em casa do general Ívolguin entre a mãe, Nina Alieksándrovna, a irmã, Vária (acima mencionada na extensão de seu nome) e o irmão, Gánia. A presença desse retrato, entre as coisas de Gánia, é o índice, para Nina e Vária, da aceitação por parte de Nastácia (desafeto de ambas) do pedido de casamento feito pelo filho e irmão respectivamente.

No desdobramento da cena e na iminência de responder aos questionamentos de Nina a respeito de seu conhecimento efetivo sobre o assunto, Mychkin, na companhia das duas mulheres, vê irromper porta à dentro Gánia acompanhado por Ptítzin.

Sendo que, o que se passa chega a nós, leitores, da seguinte maneira:

—É hoje, Gánia? — perguntou de repente Nina Alieksándrovna.

- Hoje o quê? - Gánia esboçou animar e súbito investiu contra o príncipe. - Ah, estou entendendo, até aqui o senhor!... Ora, o que é isso, o que afinal o senhor tem, alguma doença? Não pode se conter? Pois entenda finalmente, sua alteza... (DOSTOIÉVSKI, 2002, p. 128).

E, apesar da intervenção de Ptítzin “ Neste caso a culpa é minha, Gánia, e de ninguém mais (...)" ${ }^{16}$, ao esnobe e ganancioso Gánia, "Nem the passava pela cabeça desculpar-se diante do príncipe" 17.

É, portanto, sob esse recorte da narrativa que "No auge da violência endógena, um fenômeno ocorre e, devido ao êxito com que permite controlar os efeitos disruptivos da mimesis, tende a repetir-se: a violência indiscriminada, de todos contra todos, torna-se dirigida contra um único membro do grupo" ${ }^{18}$. E essa violência, no caso desse acontecimento contido na primeira parte do romance, não é necessariamente física, mas, opera no nível das emoções e das paixões e, portanto, "Eis aí o sentimento que

\footnotetext{
${ }^{16}$ Loc. cit.

${ }^{17} \mathrm{Id}$.

${ }^{18}$ GIRARD, 2009, p 21
} 


\section{Revista do SELL}

v. 6 , no. 2

ISSN: $1983-3873$

chamamos de ódio" 19. Eis aí também a configuração do "bode expiatório", mecanismo pelo qual o sistema mimético se manifesta e ao mesmo tempo sustém-se, posto que mitigue seus próprios efeitos, quando esses atingem a escala epidêmica.

Assim,

(...) o desejo mimético é contagioso e pode agravar-se na exata proporção em que um número maior de agentes encontrar-se envolvido no curtocircuito da rivalidade mimética. Se nenhuma forma de controle da dimensão apropriativa da mimesis for desenvolvida, a própria formação social pode vir a desintegrar-se em meio a um conflito generalizado. (GIRARD, 2009, p 21).

Essa espécie de mal autoimune, que segundo Girard perpassa todo o processo civilizatório, acompanhando os movimentos humanos ao longo da História e fazendo-se "necessário" à dinâmica do homem em sociedade, seria um desdobramento da "forma endógena de mediação", isto é, da "mediação interna", aquela em que "[...] o modelo se encontra perigosamente próximo do sujeito mimético [...]" ${ }^{20}$. Por conseguinte, quanto maior for essa proximidade, maiores serão as chances de a imitação intensificar o confronto.

No entanto, não se pode deixar de notar uma lacuna - dentre tantas outras existentes no romance -, por onde avaliar a disposição de personagens como Nina Alieksándrovna na arquitetura da trama, torna-se uma tarefa melindrosa.

Nas linhas anteriores foi mencionada a projeção das frustrações e a canalização do ódio sobre Mychkin, na medida em que tais espectros premem-no ao longo da narrativa. Todavia, não é possível entrever a ação de Nina ao questioná-lo pela segunda vez, já que, num espaço de tempo intermitente à resposta proferida na ocasião de sua primeira pergunta, ela então dispara:

Quando eu Ihe pergunto sobre Gravila Ardaliónovitch não estou Ihe interrogando nada - observou Nina Alieksándrovna -, o senhor não deve enganar-se a esse respeito. Se existe alguma coisa que ele mesmo pode me confessar eu não quero ficar sabendo à revelia dele. Eu estou the perguntando propriamente, porque há pouco, na sua presença e depois que o senhor saiu, respondeu assim à minha pergunta sobre o senhor: "Ele está sabendo de tudo e não há razão para cerimônias!...”. O que isto

\footnotetext{
${ }^{19}$ Op. cit., p 34.

${ }^{20}$ Op. cit., p.19.
} 


\section{Revista do SELL \\ v. 6 , no. 2 \\ ISSN: $1983-3873$}

significa? Isto é, eu gostaria de saber em que medida... (DOSTOIÉVSKI, 2002, p. 128).

Ora, se esse aparte familiar, ao qual se refere Nina, de fato ocorreu, há de ter sido em um momento no qual as cortinas desse drama eslavo degringolaram propositada ou despropositadamente diante dos leitores. Pois ao retrocederem-se dez páginas atrás quando da introdução do príncipe à "metade familiar" ${ }^{21}$ da casa-pensão em que Gánia mora com os familiares -, após serem comunicadas breves informações a respeito de Ptítzin, dando-se ênfase, sobretudo, à sua situação em relação à Varvara e Nina, deparase com um trecho no qual a concatenação fica se não perdida, em grande parte comprometida.

Observemo-lo, portanto:

Diante da recomendação minuciosa porém entrecortada de Gánia (que cumprimentou à mãe muito secamente, não dirigiu nenhum cumprimento à irmã e no mesmo instante levou Ptítzin do cômodo sabe-se lá para onde), Nina Alieksándrovna disse ao príncipe algumas palavras carinhosas e mandou Kólia, que apareceu à porta, leva-lo para o quarto do meio. (DOSTOIÉVSKI, 2002, p. 118).

Seria tentador - e não menos plausível -, diante tal circunstância, supor que essa interdita recomendação aludiria ao célere diálogo entre Nina e Gánia, mencionado por ela mesma ao príncipe, como se pode conferir na citação da página anterior. Entretanto, um pouco adiante, Gánia reporta ao príncipe o comedimento nos seguintes termos:

Duas palavras, príncipe, eu tinha até me esquecido de lhe falar além daqueles... assuntos. Tenho um pedido: faça-me o favor - se isso não lhe causar grande esforço -, não tagarele aqui sobre o que acabou de acontecer entre mim e Aglaia, nem lá sobre o que o senhor vai encontrar aqui; porque aqui também há bastante coisa revoltante. Aliás, com os diabos, pelo menos hoje se contenha. (DOSTOIÉVSKI, 2002, p. 120).

Mediante isso, poder-se-ia indagar até que ponto Nina (personagem insuspeita até então, posto ser apresentada no romance como uma mulher honrada) poderia estar manipulando o príncipe, por meio da dissimulação, em beneficio de seu interesse em saber aquilo que o filho não lhe revelou.

Entretanto, também, seria possível que, de fato, Gánia estivesse tão confuso a ponto de deixar escapar o referido "Ele está sabendo de tudo e não há razão para

\footnotetext{
${ }^{21}$ Op. cit., p. 117.
} 


\section{Revista do SELL}

v. 6 , no. 2

ISSN: $1983-3873$

cerimônias!" Ou ainda, dado sua índole, não poder-se-ia duvidar que Gánia estivesse a fazer uma espécie de jogo de confabulações, no qual o único objetivo seria o de desmoralizar o intruso.

Não podemos saber ao certo. Se no romance há, como há um bom tempo vem se afirmando, um inflacionamento do universo subjetivo, acompanhado (paradoxalmente) do estridular polifônico, toda forma de vislumbre, seja qual for, implica o revolver-se em espesso estofo humano.

Entretanto, em nenhuma outra personagem a angústia de se deparar com "aquele por quem o escândalo é revelado" é maior do que em Ipolit Teriéntiev, o jovem tísico. Isso porque, para esse novo niilista mais do que para qualquer outro, a aposta numa redenção racionalista ou em um projeto de dogmatização materialista apresenta-se contraditório. A doença que o degenera, ao mesmo tempo em que o faz desejar a vida, também lhe indica a insustentável condição biológica do Homem. E, esse horror escatológico (ou seja, a morte) é única verdade capaz de se suster.

Logo, após invadir, na companhia dos demais colegas do grupo dos niilistas, a reunião feita na casa do príncipe, com a intenção de pôr em pauta forçosamente a discussão da "nova causa", Ipolit, ao aperceber-se como foco do desdém da maioria ali presente, desabafa de forma profusa:

A senhora sabe que eu vim para a cá a fim de ver as árvores? Aquelas ali... (ele apontou para as árvores do parque), não é engraçado, hein? Pois aí não há nada de engraçado, há? - perguntou sério à Lisavieta Prokófievna e súbito ficou pensativo; um instante depois levantou a cabeça e por curiosidade ficou procurando com os olhos entre os presentes. Procurava levguiêni Pávlovitch, que estava bem perto, à direita, no mesmo lugar de antes - mas ele já havia esquecido e o procurava em outro. - Ah, o senhor não foi embora! - Finalmente o encontrou. - Há pouco o senhor ria sem parar porque eu queria falar um quarto de hora ao pé da janela... Sabe que eu não tenho dezoito anos: passei tanto tempo deitado nesse travesseiro, tanto tempo olhando por essa janela e tanto tempo pensando... em todos...que ... Morto não tem idade, o senhor sabe. Ainda na semana passada eu pensei nisso quando acordei no meio da noite... $E$ sabe de que o senhor tem medo? O senhor tem medo da nossa sinceridade mais do que de tudo, mesmo que nos despreze! Eu também pensei nisso à noite quando estava querendo rir da senhora, Lisavieta Prokófievna? Não, eu não ria da senhora, eu queria apenas elogiá-la... Kólia me disse que o príncipe a chamou de criança... isso é bom... Sim, é que eu... ainda queria.... Cobriu o rosto com as mãos e ficou pensativo [...]

Veja só: quando ainda agora a senhora se despedia, eu pensei de repente: vejas essas pessoas, nunca mais voltarei a vê-las, nunca mais! $E$ as árvores também - vai haver uma parede de tijolo, vermelha, da casa de Meierov ... defronte da minha janela... bem, fale você de tudo isso a eles... 


\section{Revista do SELL}

v. 6 , no. 2

ISSN: $1983-3873$

tente dizer; eis uma beldade... mas tu estás morto, apresenta-te como morto , diz que ao "ao morto é permitido dizer tudo... e que a princesa Mária Alieksêievna não vai dizer desaforos , quá-quá!... Os senhores são terrivelmente cruéis! - pronunciou de repente com uma indignação triste, olhando para todos. [...] E queria ser um homem de ação, eu tinha o direito... Oh, como eu queria muito! Agora eu não quero nada, não quero querer nada, eu me dei a palavra de já não querer nada; que procurem, que procurem a verdade sem mim! É, a natureza é debochada! Por que ela - retomou ele com fervor -, por que ela cria os melhores seres para debochar deles? Ela agiu de tal maneira que o único ser que na face da terra foi reconhecido como a perfeição ... ela agiu de tal modo que, depois de mostrá-lo aos homens, destinou a ele mesmo dizer por que motivo se havia derramado tanto sangue, e que se tivesse sido derramado todo de uma só vez as pessoas teriam se afogado na certa! Oh, é bom que eu esteja morrendo! Talvez eu também viesse a dizer alguma mentira terrível, a natureza me levaria a isso!... Eu não perverti ninguém... Eu quero viver para a felicidade de todos os homens, para as descobertas e para anunciar a verdade... Eu fitava pela janela o muro de Meyer e pensava apenas em falar um quarto de hora e convencer a todos, a todos, e que deu? Em nada! Deu em que o senhores me desprezam! Então não sou necessário, quer dizer, um imbecil, quer que está na hora! E não consegui deixar nenhuma lembrança! Nenhum som, nenhum vestígio, nenhuma realização , não divulguei nenhuma convicção!....Não riam de um tolo! Esqueçam! Esqueçam tudo...esqueça, por favor, não sejam tão cruéis! Saibam os senhores que se não tivesse apanhado a tísica eu mesmo teria me matado... [...] Parece que ele ainda quis dizer muita coisa mas não concluiu, lançou-se na poltrona, cobriu o rosto com as mãos e chorou como uma criancinha. (DOSTIÉVSKI, 2010, p. 336-338)

É neste ponto que toda a engenharia conceitual moderna e pós-moderna, que de alguma forma proclama a independência do Homem e the confere uma liberdade engendrada no existencialismo ateu, pensando ter resolvido o problema da transcendência divina, na verdade dele locupleta-se. Como arrazoa Girard "A simples negação de Deus não elimina a transcendência, mas faz que esta se desvie do além para o aquém. A imitação de Jesus Cristo se transforma na imitação do próximo" (GIRARD, 2009, p. 84); Ipolit conta-se entre os "melhores seres", um dos verdadeiros proclamadores da verdade ao mundo. Tal é o aspecto da "transcendência desviada": uma reinvenção da transcendência vertical divina, ou seja, sua transposição para um plano horizontal.

Destarte, esse desvio faz com que reverbere em Mychkin a "sobrenaturalidade esquecida", ou melhor, abandonada pelo Homem; uma vez que ele apresenta "... o comportamento de alguém sobrenaturalizado, divinizado - um comportamento inefável." (PONDÉ, 2003, p. 254). Justamente por esse motivo, o príncipe torna-se a personificação da consciência dos outros. 


\section{Revista do SELL}

v. 6 , no. 2

ISSN: $1983-3873$

Não obstante, dado que "Sua capacidade noética é tão espontânea, que ele parece não fazer qualquer esforço, é como se fosse sua respiração”, ele, por conseguinte, “(...) compreende o que as pessoas pensam e sentem, como no sentido original da palavra 'simpatia', isto é sentir junto com o outro" (op. cit., p.256). Por essa razão, como bem observou Frank, "o Príncipe entende que, para Ipolit, a posse imperturbada de vida por outros é uma grande injustiça, que deveria enchê-los de culpa" (FRANK, 2003, p. 439).

Mas, se no fundo Ipolit sabe que a morte será o fim de todos, deveria então reconhecer que "Num universo de iguais os fracos são a presa do desejo metafísico e chega-se ao triunfo dos sentimentos modernos: 'a inveja, o ciúme e o ódio impotente'" (GIRARD, 2009, p. 90). Ele deveria admitir que o mal ontológico, que assoma em suas cogitações, repousa sobre o desejo mediado.

Além disso, a "liberdade" como conceito existencialista, conquanto infundado logicamente, assentou grande parte dos argumentos que fundaram um dogma humanistanaturalista, cujos correligionários ainda 'insistem numa visão menos 'pessimista' da condição humana." (PONDÉ, 2003, p. 18). Por conseguinte, justamente sobre esse aspecto, de acordo com a hipótese proposta por Pondé, "a crítica religiosa de Dostoiévski faz um razoável 'estrago', iluminando as inconsistências de um mundo ridículo" (op. cit., p.21).

Porém, a crítica religiosa de Dostoiévski, contida em O ldiota, consiste num insight ainda mais desconcertante: ela emana de um movimento dialético que ao mesmo tempo em que promove um "Esforço supremo em criar uma perfeição puramente humana e individualista" demonstra que "o romance volta-se, em suma, contra sua própria 'ideia"' (GIRARD, 2011, p. 75).

Assim, ao instaurar uma "transcendência desviada" como elemento compositivo e orgânico de sua obra, Dostoiévski deita por terra justamente aquilo que os críticos nele celebraram; nas palavras de Girard: "Ele é glorificado pelo que, ainda ontem, o tornava suspeito" (GIRARD, 2009, p.278) - a saber, a liberdade das personagens em meio ao universo diegético da obra de arte literária.

Note-se, doravante, que a crítica religiosa de Dosteiévski, realizada esteticamente no "conflito polifônico infinito", no "drama multivocal como categoria essencial para descrever a condição humana que fala de si mesma" (PONDÉ, 2003, p. 26), instrumentaliza a transcendência desviada e põe em xeque - ao expor as frestas disruptivas da técnica romanesca - um topos caro à crítica pós-moderna, já que: 


\section{Revista do SELL}

v. 6 , no. 2

ISSN: $1983-3873$

A noção de liberdade é necessariamente ambígua quando aplicada ao romance. Se o romancista é livre, em compensação, fica difícil entender como suas personagens poderiam sê-lo. A liberdade não se partilha, mesmo se tratando de criatura e criador. Eis aí um dogma fundamental e o sr. Jean-Paul Sartre se gaba de provar, graças a ele, a impossibilidade de haver um Deus criador. O que é impossível a Deus não poderia ser possível ao romancista. Ou o romancista é livre e suas personagens não o são, ou as personagens são livres e o romancista, tal como Deus, não existe. (GIRARD, 2009, p.287).

A liberdade desmensurada, apregoada pelo grupo de niilistas, falhou ao tergiversar a morte. O exílio do materialismo na natureza (Rogójin perdendo sua fé enquanto contempla O Cristo Morto, de Holbein) não resolveu de modo contundente a questão da sobrenaturalidade herdada. Consequentemente, a aposta humanista (de Dostoiévski em Mychkin), que permutou teocentrismo por antropocentrismo, falhou. Aliás, o simples enaltecimento, na modernidade, do "princípio antrópico participativo" em detrimento da "teoria do desenho inteligente", revela-se uma tentativa de transcendentalização do Homem já encetada pelos renascentistas séculos atrás. O desvio da divindade teocêntrica sobrenatural perfaz o propósito de transcendência desviada.

Como assevera Girard (2009, p. 86), "No mundo de amanhã, afirmam os falsos profetas, os homens serão deuses uns para os outros." Daí que para muitos a "crítica religiosa de Dosteiévski" carrega-se de cores sórdidas e descamba para o pessimismo.

Contudo,

$\mathrm{Na}$ realidade, esse pessimismo é apenas um modo que o senso comum encontra para descrever o tipo de sensação um tanto asfixiante que brota das críticas contundentes de tais autores com relação às crenças humanistas-naturalistas." (PONDÉ, 2003, p. 18).

Sob essa perspectiva, a crítica religiosa apresentada em $O$ ldiota, "trata-se, na realidade, de uma filosofia da desgraça" (op. cit., p.23). Embora a única ascese que o "herói" do romance alcance seja a epilética ${ }^{22}$, ainda assim, e talvez por isso mesmo:

(...) com uma integridade que nunca será demais louvar, Dostoiévski submete sem temor suas convicções mais sagradas ao mesmo teste que usa para pôr à prova as dos niilistas: o que significariam para a vida

\footnotetext{
22 “(...) pois Míchkin não se dá bem no final; o Cristo de Dostoiévski não dá certo, não consegue realizar a missão que tinha tomado para si: salvar Nastácia Filíppovna” (op. cit., p.254).
} 


\section{Revista do SELL}

v. 6 , no. 2

ISSN: $1983-3873$

humana se fossem levadas a sério e ao pé da letra, se tomadas em toda a sua extensão como norma de conduta. (FRANK, 2003, p.449).

Emendemos, sem maiores pretensões, o biógrafo: Dostoiévki na verdade submete à sua crítica religiosa o "projeto moderno o qual chama de 'virtude sem o Cristo' ou 'a salvação sem Deus', um projeto de aposta na natureza." (PONDÉ, 2003, p. 258), que, por ser o âmago de sua crítica, "... vai exatamente lembrando Nietzsche 'ao humano, demasiadamente humano" (loc. cit.). E, porque não acrescentar: vai lembrando a Freud, e a todos que apostam no racionalismo metafísico ou cientificista, que o "mal estar na civilização" na realidade consiste no impulso em direção a uma transcendência desviada, escamoteadora de uma sobrenaturalidade esquecida, porquanto banida.

\section{Referências}

DOSTOIÉVSKI, Fiódor. O idiota. trad. Paulo Bezerra. São Paulo: Ed. 34, 2002.

FISTER, Barbara. On the Threshold of Representation: the function of the Holbein Christ in the Idiot. Disponível em: <

http://homepages.gac.edu/ fister/ThresholdofRepresentation.html>. Acesso em: 2 jun. 2014.

FOCCHI, Guilherme Rubino de Azevedo. Epilepsia e religiosidade. Psychiatry on line Brasil, São Paulo, v.18, jun. 2013. Disponível em:

$<$ http://www.polbr.med.br/ano01/artigo0701 b.php >. Acesso em: 01 jul. 2013.

FRANK, Joseph. O idiota. In: Dostoiévski: os anos milagrosos, 1865-1871. São Paulo, SP: EDUSP, 2003.

GIRARD, René. Metafísica do subsolo. In: Dostoiévski: do duplo à unidade. São Paulo, SP: É Realizações, 2011.

Mentira romântica e verdade romanesca. São Paulo, SP: É Realizações, 2009.

PARANHOS, Flávio Rocha Lima. O odor deletério de Dostoiévski. Revista Filosofia, São Paulo, n. 76, p. 24-29, set. 2012.

PONDÉ, Luiz Felipe. Crítica e profecia: a filosofia da religião em Dostoievski. São Paulo, SP: Editora 34, 2003. 